\title{
Using the energy signature method to estimate the effective U-value of buildings
}

\author{
Gustav Nordström $^{1}$, Helena Johnsson ${ }^{1}$ and Sofia Lidelöw ${ }^{1}$ \\ ${ }^{1}$ Division of Structural and construction engineering, Luleå University of Technology, \\ Sweden SE-971 87 LULEÅ Sweden
}

\begin{abstract}
The oil crisis of the 1970s and the growing concern about global warming have created an urge to increase the energy efficiency of residential buildings. Space heating and domestic hot water production account for approximately $20 \%$ of Sweden's total energy use. This study examines the energy performance of existing building stock by estimating effective U-values for six single-family houses built between 1962 and 2006. A static energy signature model for estimating effective Uvalues was tested, in which the energy signature was based on measurements of the total power used for heating and the indoor and outdoor temperatures for each studied house during three winter months in northern Sweden. Theoretical U-values for hypothetical houses built to the specifications of the Swedish building codes in force between 1960 and 2011 were calculated and compared to the U-values calculated for the studied real-world houses. The results show that the increasingly strict $\mathrm{U}$-value requirements of more recent building codes have resulted in lower U-values for newer buildings, and that static energy signature models can be used to estimate the effective U-value of buildings provided that the differences between the indoor and outdoor temperatures are sufficiently large.
\end{abstract}

Kewords: Energy signature, building energy use, houses in cold climate, average U-values

\section{Introduction}

Residential buildings account for about $40 \%$ of Sweden's total energy use, with space heating and hot water alone being responsible for around $20 \%$ of the total (Energimyndigheten 2012). There is therefore great interest in improving building performance. A building's performance is dependent on its design and the way in which it was built, and so building codes can be seen as tools that can be used to increase systematic efficiency and to mandate improvements in the thermal properties of new buildings. Building performance is also sensitive to users' behavior and consumption of building services (Guerra-Santin and Itard 2010; Lundstrom 1986). Since the establishment of the first Swedish national building code in the 1950 s, factors such as the oil crisis of the 1970s and the growing awareness of the problems posed by global warming have increased the demand for buildings with 
high energy performance. This has, in turn, led to changes in the way we build our houses. Since 1920, the dominant housebuilding technique used in Sweden has been to construct a light timber-framed structure with evenly spaced studs. In more recent years, it has become common to use thicker walls with one or two horizontal layers of studs (Nordling and Reppen 2009). Figure 1.1 shows the maximum average U-values $\left[\mathrm{W} / \mathrm{m}^{2 \circ} \mathrm{C}\right.$ ] permitted under Swedish building codes from the 1960s onwards. To facilitate comparisons between codes from different years, all U-values were calculated for a hypothetical house with a floor area of $16 \times 10$ $\mathrm{m}$, an inside height of $2.5 \mathrm{~m}$, a window area of $19.5 \mathrm{~m}^{2}(15 \%)$, and an envelope area of $450 \mathrm{~m}^{2}$. The building codes of 1960 and 1980 specified maximum Uvalues for each building part such as the walls, roof and floor, while the building code of 1988 imposed a cap on the average U-value of the building envelope. Conversely, both the current code and that issued in 2006 stipulate an upper limit on the energy usage per square meter of heated floor area $\left[\mathrm{kWh} / \mathrm{m}^{2}\right]$, with the limit values for houses with electrical heating (excluding household electricity) being different to those for houses with non-electrical heating. Thus the U-values for 2006 and 2011 in Figure 1.1 also include ventilation losses in the house whereas the limits stipulated between 1960 and 1988 relate to transmission losses alone.

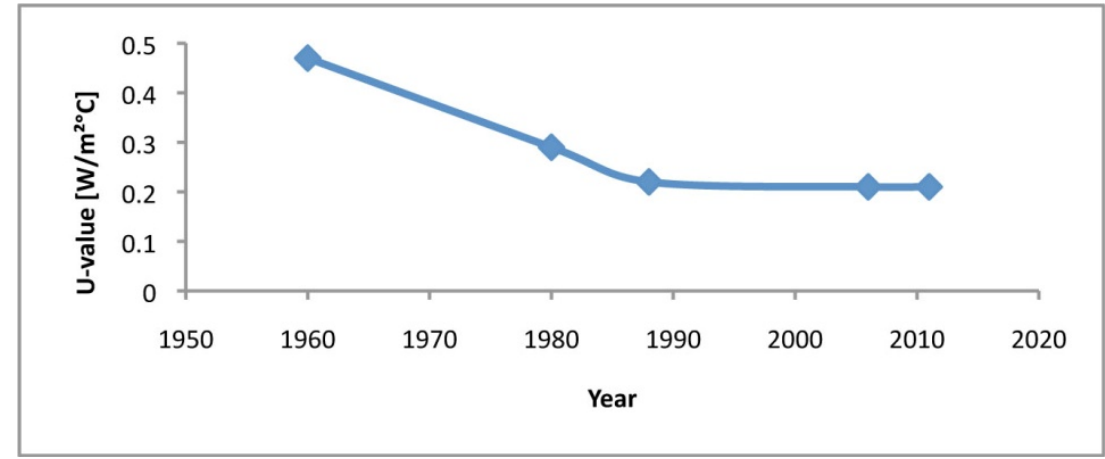

Figure 1.1 Caps on average U-values mandated by Swedish building codes between 1960 and the present day.

The case study discussed herein was conducted to develop a method based on a static energy signature model for estimating effective U-values for wooden singlefamily homes in a cold climate. A number of houses constructed between 1962 and 2006 were investigated; the nominal U-values that would be expected for such buildings are shown in Figure 1.1. The developed method was used to determine whether the changes in the national building code over the years have yielded practical increases in building performance. 


\section{Theory}

\section{Energy signature}

Energy signature models estimate the overall power loss $\left(\mathrm{K}_{\mathrm{TOT}}\right)$ as a function of the difference between the indoor $\left(\mathrm{T}_{\mathrm{i}}\right)$ and outdoor $\left(\mathrm{T}_{\mathrm{e}}\right)$ temperatures, as described by Sjögren (2007) and Hammarsten (1987):

$$
K_{T O T}\left(T_{i}-T_{e}\right)=P_{H}+P_{G}-P_{D Y N}
$$

Here, $\mathrm{K}_{\text {тот }}$ is the sum the of heat losses from the building due to transmission and ventilation, $\mathrm{P}_{\mathrm{H}}$ is the power supplied for heating, $\mathrm{P}_{\mathrm{G}}$ is power gained at no cost ("free power"), and $\mathrm{P}_{\mathrm{DYN}}$ is power that is dynamically stored and released. If heat is supplied via a district heating system, $\mathrm{P}_{\mathrm{H}}$ is given by the total amount of power drawn from the district heating system $\left(\mathrm{P}_{\mathrm{DH}}\right)$ minus that used for heating water $\left(\mathrm{P}_{\mathrm{DHW}}\right)$ and that lost from the system $\left(\mathrm{P}_{\mathrm{L}}\right)$ :

$$
\mathrm{P}_{\mathrm{H}}=\mathrm{P}_{\mathrm{DH}}-\mathrm{P}_{\mathrm{DHW}}-\mathrm{P}_{\mathrm{L}}
$$

The free power $\left(\mathrm{P}_{\mathrm{G}}\right)$ consists of power gained from insolation $\left(\mathrm{P}_{\mathrm{SUN}}\right)$, household electricity $\left(\mathrm{P}_{\mathrm{HE}}\right)$, household operating electricity $\left(\mathrm{P}_{\mathrm{BE}}\right)$ and heat generated by the actions of the building's occupants $\left(\mathrm{P}_{\mathrm{P}}\right)$ :

$$
\mathrm{P}_{\mathrm{G}}=\mathrm{P}_{\mathrm{SUN}}+\mathrm{P}_{\mathrm{HE}}+\mathrm{P}_{\mathrm{BE}}+\mathrm{P}_{\mathrm{P}}
$$

$\mathrm{K}_{\mathrm{TOT}}$ can then be described as:

$$
\mathrm{K}_{\mathrm{TOT}}\left(\mathrm{T}_{\mathrm{i}}-\mathrm{T}_{\mathrm{e}}\right)=\mathrm{P}_{\mathrm{DH}}-\mathrm{P}_{\mathrm{DHW}}-\mathrm{P}_{\mathrm{L}}+\mathrm{P}_{\mathrm{SUN}}+\mathrm{P}_{\mathrm{HE}}+\mathrm{P}_{\mathrm{BE}}+\mathrm{P}_{\mathrm{P}}-\mathrm{P}_{\mathrm{DYN}}
$$

Where $\mathrm{K}_{\text {Tот }}$ equals $\mathbf{P}_{\text {тот }}$ :

$$
\mathrm{K}_{\mathrm{TOT}}\left(\mathrm{T}_{\mathrm{i}}-\mathrm{T}_{\mathrm{e}}\right)=\mathrm{P}_{\text {TOT }}
$$

\section{Method}

\subsection{Monitored buildings}

The case study was based on measurements conducted in six inhabited detached single family houses in the city of Luleå, Sweden. The city has a subarctic climate with a yearly average temperature of $1^{\circ} \mathrm{C}$ (SMHI 2011). All of the houses have wooden structures, wooden or brick façades and are connected to the district heating system of the city. The houses were constructed in 1962, 1967, 1983, and 1987, with the last two having been built in 2006. As such, they were constructed under a range of different building codes, using various techniques. Some of the 
more important properties of the studied buildings are presented in Table 3.1. The study focused on measurements acquired during the winter of 2011-2012 between November 2011 and February 2012. Large variations in outside temperature are common during this period, which creates differences in temperature between indoor and outdoor air $(\Delta \mathrm{T})$ of $15^{\circ} \mathrm{C}$ to $50^{\circ} \mathrm{C}$; large $\Delta \mathrm{T}$ values make it easier to accurately estimate $\mathrm{K}_{\mathrm{TOT}}$.

Table 3.1 Key properties of the six single-family houses examined in this work.

\begin{tabular}{||l|c|c|c|c|c|c||}
\hline \hline House & 1 & 2 & 3 & 4 & 5 & 6 \\
\hline Stories* & $1.5^{* *}$ & 1 & 1.5 & 1 & 1 & 1.5 \\
\hline Year of construction & 1962 & 1967 & 1983 & 1987 & 2006 & 2006 \\
\hline $\begin{array}{l}\text { Insulation thickness } \\
{[\mathrm{mm}]}\end{array}$ & \multicolumn{5}{|l||}{} \\
\hline -Wall & 70 & 130 & 180 & 245 & 215 & 215 \\
\hline -Roof & 200 & 145 & 270 & $435 / 290$ & 450 & 315 \\
\hline -Floor & 0 & 50 & 200 & 240 & 190 & 200 \\
\hline Envelope area $\left[\mathrm{m}^{2}\right]$ & 382 & 298 & 454 & 459 & 523 & 596 \\
\hline $\begin{array}{l}\text { Heated floor area }\left[\mathrm{m}^{2}\right] \\
\text { house/garage }\end{array}$ & 210 & 100 & $168 / 29$ & $174 / 32$ & $142 / 38$ & $197 / 45$ \\
\hline $\begin{array}{l}\text { Inhabitants } \\
\text { adults/children }\end{array}$ & $\begin{array}{c}3 \\
(2 / 1)\end{array}$ & $\begin{array}{c}3 \\
(2 / 1)\end{array}$ & $\begin{array}{c}2 \\
(2 / 0)\end{array}$ & $\begin{array}{c}4 \\
(2 / 2)\end{array}$ & $\begin{array}{c}3 \\
(2 / 1)\end{array}$ & $\begin{array}{c}4 \\
(2 / 2)\end{array}$ \\
\hline \hline
\end{tabular}

*1.5 denotes one and half storey houses that have a finished attic.

**This house also has a basement that extends beneath the entire building.

\subsection{Input data}

A Saber measurement system (KYAB, Sweden) was installed in each monitored house. The system consists of a measurement unit connected to the Internet that collects all data sampled by the sensors in each house. Sampling was conducted once per minute and the measurements were later converted to daily averages.

\subsubsection{Temperature}

$T_{i}$ and $T_{e}$ were measured using temperature sensors (one indoors and one outdoors) that were connected to the Saber unit via a cable. The sensors were factory calibrated to read temperatures of $-40^{\circ} \mathrm{C}$ to $+80^{\circ} \mathrm{C}$ with an accuracy of $\pm 0.1^{\circ} \mathrm{C}$. Indoor sensors were placed in a bedroom, hallway or living room away from heat sources and not in direct sunlight. Outside sensors were placed on the building façades in locations that would minimize the level of incident sunlight.

\subsubsection{Power supplied for heating}

$\mathrm{P}_{\mathrm{DH}}$ and $\mathrm{P}_{\mathrm{DHW}}$ were measured and separated by the Saber unit using a previously established (Yliniemi 2007) and experimentally verified (Yliniemi, et al. 2009) method of estimation. The Saber unit was also used to collect data on the amount 
of power drawn from the district heating system, which was gathered via the infrared (IR) port on the existing meter in each house. The Saber unit recorded the total amount of energy drawn from the district heating system for space and water heating. Individual residential houses connected to district heating systems have no ability to store heat from the system, and so any power required for space heating or hot water is supplied on demand. Space heating generates a steady baseline use of power from the district heating system, with hot water usage generating additional spikes in usage on top of this (Yliniemi et al. 2009). It was assumed that there were no losses from the system (i.e. the value of $P_{\mathrm{L}}$ was zero) because all measurements of $\mathrm{P}_{\mathrm{DH}}$ and $\mathrm{P}_{\mathrm{DHW}}$ were conducted indoors, and all losses that occur inside the building envelope are assumed to contribute to the heating of the house. This means that all production and transportation losses occur outside of the measurement zone.

\subsubsection{Gained free power}

$\mathrm{P}_{\mathrm{SUN}}$ was assumed to be zero because the measurements were conducted during the months of November-February, during which the level of insolation in northern Sweden is very low (Sjögren et al. 2007). Luleå has about 80 hours of sunshine in October, about 10 in December, and about 60 in February (SMHI 2012). $\mathrm{P}_{\mathrm{P}}$ was estimated to $71 \mathrm{~W}$ at low activity and $119 \mathrm{~W}$ at higher activity per person (Sauer et al. 2001). Each person was assumed to spend sixteen hours per day in their house, during which they would be highly active for 8 hours and less active for the remaining eight. According to Petersson (2010) $20 \%$ of the power used to produce hot water and $75 \%$ of the electrical power usage can be considered as heat gains. Because the Saber unit recorded $\mathrm{P}_{\mathrm{DH}}$ and $\mathrm{P}_{\mathrm{DHW}}$ separately, a new term $\left(\mathrm{P}_{\mathrm{HW}}\right)$ was introduced to denote the heat gains from water heating. Electricity use was measured using existing electricity meters in each house, which were connected to the Saber unit via a pulse detector. Since $\mathrm{P}_{\mathrm{HE}}$ and $\mathrm{P}_{\mathrm{BE}}$ could not be separated, a single term denoting heat gains from electricity was introduced $\left(\mathrm{P}_{\mathrm{E}}\right)$ and calculated as $75 \%$ of the total electrical energy used.

\subsubsection{Dynamically stored/released power}

$P_{\text {DYN }}$ was assumed to have negligible effect on the results. According to Hammarsten (1987), the dynamics of the building can be neglected if twenty-four hour averages are used as input data for the energy signature model as was the case in this work. The assumption that dynamics can be ignored is strengthened by the fact that the case study houses are made of wood, which is a light construction material that stores relatively little energy.

\subsubsection{Determination of $\mathbf{P}_{\text {TOT }}$}

Using the above assumptions, $\mathrm{P}_{\text {TOт }}$ was calculated for each house.

$$
\mathrm{P}_{\mathrm{TOT}}=\mathrm{P}_{\mathrm{H}}+\mathrm{P}_{\mathrm{HW}}+\mathrm{P}_{\mathrm{E}}+\mathrm{P}_{\mathrm{P}}
$$




\subsection{Data management and evaluation}

All collected data were downloaded from the Saber units' web server and imported to Excel. The measured outdoor temperatures at the studied houses were compared to detect any sudden peaks or drops that might indicate malfunctions or the introduction of external heat sources. The indoor temperatures were also checked to ensure that they remained relatively steady and contained no peaks due to the introduction of new heat sources. $\mathrm{P}_{\text {Tот }}$ was calculated using equation 3.1 and was plotted as a function of the difference between the outdoor and indoor temperatures $(\Delta \mathrm{T})$ for each house. Linear regression was then used to calculate $\mathrm{K}_{\mathrm{TOT}}$ from the slopes of the plots. The $\mathrm{K}_{\mathrm{TOT}}$ values obtained in this way were divided by the area (A) of the envelope for the corresponding building from Table 3.1 to give a set of estimated average $\mathrm{U}$-values.

\section{Results and analysis}

Figure 4.3 shows a plot of $\mathrm{P}_{\text {TOт }}$ against $\Delta \mathrm{T}$ for houses 1-6 over the period between November and February. House 1 changed owners in the beginning of December, which meant that the measuring systems had to be removed. There is thus no data from house 1 for the period between December and February, which were the coldest months of the measurement period and thus had the highest $\Delta \mathrm{T}$ values. Figure 4.1 shows the calculated U-values for the period between November and February as a function of the year in which the houses were constructed. No usable temperature data was obtained for house 4 during January. To compensate for this, the indoor temperature for January was assumed to be equal to the average for the preceding months and the outdoor temperature was assumed to be equal to the outdoor temperature measured at a house located approximately $1 \mathrm{~km}$ away from house 4 on the same river. The average difference between the measured temperatures for houses 3 and 4 was $0.44^{\circ} \mathrm{C}$, with a peak difference of $5.2^{\circ} \mathrm{C}$ during one day. There were some problems with the temperature measurements in house 5 that made some of the expected indoor and outdoor temperature measurements unavailable. The missing indoor values were replaced with the average measured indoor temperature over the entire experimental period. In addition, the Saber unit for this house suffered from a driver malfunction that caused it to stop recording the outdoor temperature below $0^{\circ} \mathrm{C}$. The outdoor temperature for house 5 was therefore assumed to be identical to that for house 6 , which is located about $100 \mathrm{~m}$ away from house 5 . The average difference between the measured outdoor temperatures for houses 5 and 6 was $0.84^{\circ} \mathrm{C}$, with a peak difference of $2.83^{\circ} \mathrm{C}$. Due to the missing data, house 1 was also investigated for the time period August to November and house 2 was used as reference house for this period (Figure 4.1). Based on this time period house 1 has a calculated U-value of $0.58 \mathrm{~W} / \mathrm{m}^{2 \circ} \mathrm{C}$ and house 2 a calculated U-value of $0.50 \mathrm{~W} / \mathrm{m}^{2}{ }^{\circ} \mathrm{C}$. Due to a lack of data from December and January, the $\Delta \mathrm{T}$ span for house 1 is rather narrow, which makes the accuracy of the regression and the derived $U$-value uncertain $\left(R^{2}=0.55\right)$. The calculat- 
ed U-value for house 1 differs from that for the other house constructed in the 1960s by an unreasonable amount, Figure 4.2.

Table 3.1 shows that house 1 is less well-insulated than house 2, suggesting that its $\mathrm{U}$-value should be higher. A more realistic $\mathrm{U}$-value $\left(0.58 \mathrm{~W} / \mathrm{m}^{2 \circ} \mathrm{C}\right)$ for house 1 with a better model fit $\left(\mathrm{R}^{2}=0.83\right)$ was achieved when considering data from the period between August and November (Figure 4.1). It should however, be noted that the U-value for house 2 calculated based on data gathered between August and November was lower than that calculated for the period between November and February. This implies that the U-value of house 1 for the August November period would also be lower than that which would have been measured at higher $\Delta \mathrm{T}$ values. The goodness of fit of the regression for house 2 was high $\left(\mathrm{R}^{2}\right.$ $=0.97$ ), which implies that the assumption of a linear relationship between the power expended on heating and the temperature difference is valid. House 3 has the lowest measured U-value of all those measured in this work $\left(0.26 \mathrm{~W} / \mathrm{m}^{2}{ }^{\circ} \mathrm{C}\right)$ and a good model fit $\left(\mathrm{R}^{2}=0.96\right)$.

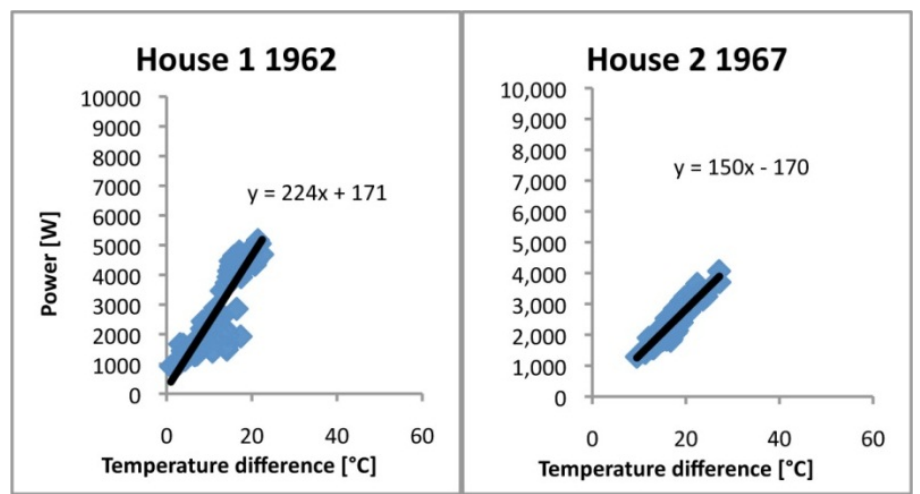

Figure 4.1 The total power $\left(\mathrm{P}_{\mathrm{TOT}}\right)$ plotted against the temperature difference $(\Delta \mathrm{T})$ for houses 1 and 2 between August and November

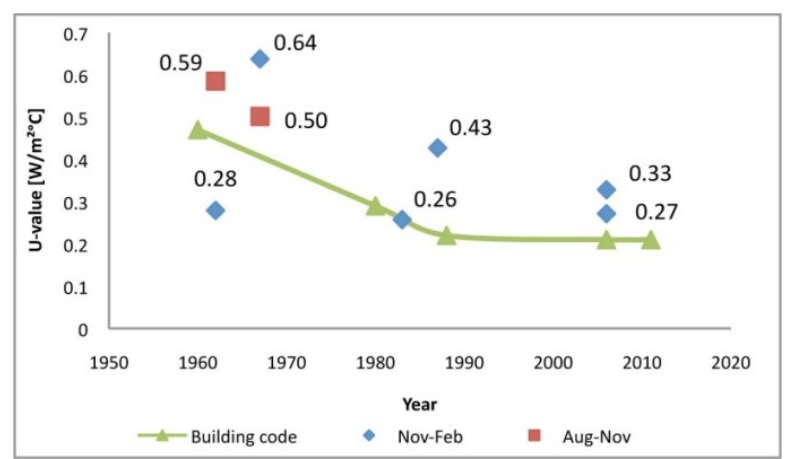

Figure 4.2 U-values plotted against the year of construction of the studied houses superimposed on the maximum average $\mathrm{U}$-values permitted by the corresponding building codes as shown in Figure 1.1 
The U-value calculated for house 4 is rather high and there is considerable uncertainty in the corresponding dataset due to the problems encountered in recording its indoor and outdoor temperatures. Because of this the curve in Figure 4.3 has more variation than the others and the regression analysis yielded an $\mathrm{R}^{2}$ value of only 0.86 . The calculated U-value for house 5 (built in 2006) was $0.27 \mathrm{~W} / \mathrm{m}^{2 \circ} \mathrm{C}$ which is close to that required by the 2006 building code. The model fit for this house was also very good $\left(\mathrm{R}^{2}=0.95\right)$. The calculated U-value for house 6 was $0.34 \mathrm{~W} / \mathrm{m}^{2 \circ} \mathrm{C}$, which is above the limit specified in the building code. The relatively poor model fit of the regression $\left(\mathrm{R}^{2}=0.91\right)$ for this house, together with the wide spread of measured temperatures is probably due to the residents' use of a stove.

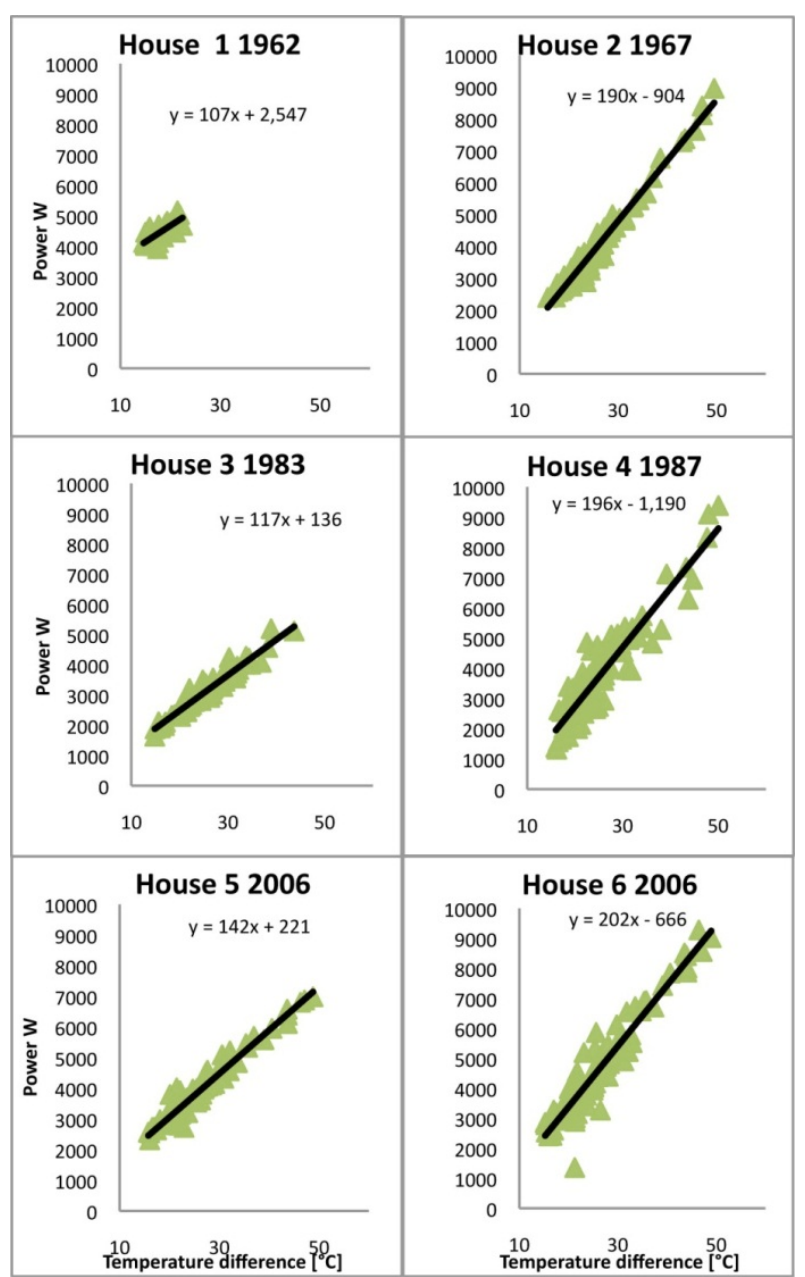

Figure 4.3 The total power usage $\left(\mathrm{P}_{\mathrm{TOT}}\right)$ as a function of the inside-outside temperature difference $(\Delta \mathrm{T})$ for houses 1-6 between November and February 


\section{Discussion}

\subsection{Effect of building regulations on energy performance}

The increasingly rigorous U-value requirements specified by the Swedish building codes over time are reflected in lower U-values for newer houses. However, the results presented in Figure 4.2 show that the U-values of all houses considered in this work were above those required by the building codes in force when they were constructed; in this context it should be noted that only transmission losses were considered in the requirements of building codes prior to 2006 . The gap between the values specified in building codes and those achieved in practice is illustrated by house 2 (built in 1967), which has an effective U-value of $0.64 \mathrm{~W} / \mathrm{m}^{2}{ }^{\circ} \mathrm{C}$ compared to the upper limit of $0.47 \mathrm{~W} / \mathrm{m}^{2}{ }^{\circ} \mathrm{C}$ specified in the building code of the time for transition losses alone. Another example is House 4, which was advertised as a "low energy house" at the time of construction and was expected to meet or only modestly exceed the requirements set out in the building code in force when it was constructed. Table 1.1 shows that it has a level of insulation comparable to or better than that found in newer houses. However, its effective U-value was actually higher than that for house 3 (Figure 4.2), which implies that the measured $\mathrm{P}_{\text {TOT }}$ was affected by some factor that the energy signature model did not account for.

\subsection{Applicability of static energy signature models in a cold climate}

The energy signature method provides a straightforward way of estimating a house's effective U-value. Because the method is most reliable when the difference between indoor and outdoor temperatures is large, it is advantageous to estimate the U-value under cold conditions. The method is sensitive to interference from external heat sources such as fireplaces. In addition, the reliability of the energy signature method for houses with basements has yet to be explored. Both Hammarsten (1984) and Westergren et al. (1999) have compared the performance of static and dynamic models for the energy signature method and have discussed the problems associated with the dynamics of heat exchange in buildings. Hammarsten recommends using daily or weekly averages for static models, while Westergren et al. recommended only weekly averages. Daily averages were used in this work, which produced realistic estimated U-values. As such, our results support the recommendation of Hammarsten (1984). User behavior was not considered in this work, but its effects can be appreciated by comparing houses 3 and 4. House 3 is occupied by a childless middle aged couple whereas house 4 belongs to a middle aged couple with two sport-playing teenagers. This probably explains why the electricity and hot water use of house 4 were three and fifteen times greater, respectively, than those in house 3 between November and February. To complement this case study, a theoretical calculation of the average U-values for 
the studied properties is planned, together with a survey of the user behavior of the inhabitants of the case study houses.

\section{Acknowledgment}

Financial support from the European regional development fund via the Interreg IVA North program is gratefully acknowledged.

\section{References}

Sauer HJJ, Howell RH. Coad WJ (2001) ASHRAE handbook, fundamentals 2001. American Society of Heating, Atlanta

Energimyndigheten 2012 Energiläget 2011. Eskilstuna

Guerra-Santin O, Itard L 2010 Occupants' behaviour: Determinants and effects on residential heating consumption. Build Res Inf 38:318-338. doi: 10.1080/09613211003661074

Hammarsten S 1984 Estimation of energy balances for houses. Dissertation, Royal Institute of Technology

Hammarsten S 1987 A critical appraisal of energy-signature models. Appl Energy 26:97-110. doi: 10.1016/0306-2619(87)90012-2

Lundstrom E 1986 Occupant influence on energy consumption in single-family dwellings. D5: Swedish Council for Building Research, Stockholm

Nordling L, Reppen L 2009 Så byggdes villan: Svensk villaarkitektur från 1890 till 2010. Forskningsrådet Formas, Stockholm

Petersson B 2010 Tillämpad byggnadsfysik. Studentliteratur, Lund

Sjögren JU, Andersson S, Olofsson T 2007 An approach to evaluate the energy performance of buildings based on incomplete monthly data. Energy Build 39(8):945-53. doi: 10.1016/j.enbuild.2006.10.010

Sjögren JU 2007 Energy performance of multifamily buildings: Building characteristics and user influence. Licentiate thesis, Umeå University

SMHI 2012 Sun statistics. http://www.smhi.se/klimatdata/meteorologi/stralning /1.3054. Accessed 13 February 2012

SMHI 2012 Temperature statistics. http://www.smhi.se/klimatdata/meteorologi /temperatur. Accessed 15 September 2011

Westergren K, Högberg H, Norlén U 1999 Monitoring energy consumption in single-family houses. Energy Build 29:247-57. doi: 10.1016/S03787788(98)00065-6

Yliniemi K 2007 A device and a method for measurement of energy for heating tap water separated from the building's heating energy-usage. Patent no. PCT/SE2006/001250 World Intellectual Property Organization

Yliniemi K, Delsing J, van Deventer J 2009 Experimental verification of a method for estimating energy for domestic hot water production in a 2-stage district heating substation. Energy Build 41:169-74.

doi:10.1016/j.enbuild.2008.08.008 